\title{
Role of Caudal Epidural Injections in the Management of Chronic Low Back Pain
}

\section{Vijay Singh, MD* and Laxmaiah Manchikanti, MD**}

Caudal epidural administration of corticosteroids is one of the commonly used interventions in managing chronic low back pain. Reports of the effectiveness of all types of epidural steroids have varied from $18 \%$ to $90 \%$. Sicard, a radiologist, was the first to describe injection of dilute solutions of cocaine through the sacral hiatus into the epidural space in 1901, to treat patients suffering from severe, intractable sciatic pain or lumbago. This was followed by an explosion of reports and evolving interest in caudal epidural steroids with two additional reports in 1901 and numerous other reports over the years.

The philosophy of epidural steroid injections is based on the premise that the corticosteroid delivered into the epidural space attains higher local concentrations over an inflamed nerve root and will be more effective than a steroid administered either orally or by in-

Sciatica is called "one of the great scourges of humanity" (1-4). Low back pain or sciatica in early days as a clinical phenomenon dates back to Domenico Cotugno's De Ischiade Nervosa Commentarius in 1764 (1-4). An understanding of the cause of low back pain, or sciatica, remained elusive until the early 1900s (3). Case reports of ruptured intervertebral discs were reported as early as 1896 but were not considered to be a cause of sciatica. Mixter and Barr (5) were the first to create widespread interest in the disc as a source of pain, with publication of their 1934 hallmark description of herniated nucleus pulposus. However, after continued research and debate, low back pain after seven decades continues to be an enigma, even in the

From Pain Diagnostic Associates, Niagara, Wisconsin and Pain Management Center of Paducah, Paducah, Kentucky. *Dr. Singh is Medical Director at Pain Diagnostic Associates. **Dr. Manchikanti is Medical Director at the Pain Management Center of Paducah. Address correspondence: Vijay Singh, MD, 1601 Roosevelt Road, Niagara, WI 54151 E-mail: vsingh@netnet.net tramuscular injection.

The clinical effectiveness evaluations fill the literature with various types of reports including randomized clinical trials, prospective trials, retrospective studies, case reports, and meta-analyses. Evidence from all types of evaluations with regards to the clinical and cost-effectiveness of caudal epidural injections is encouraging.

This review discusses various aspects of the role of caudal epidural injections in the management of chronic low back pain, including pathophysiology of low back pain, indications, clinical effectiveness and complications.

Keywords: Caudal epidural injections, steroids, chronic low back pain, complications $21^{\text {st }}$ century.

Epidural administration of corticosteroids is one of the commonly used interventions in managing chronic low back pain (6). The lumbar epidural space is accessible either by caudal, interlaminar, or transforaminal routes (6). Reports of the effectiveness of all types of epidural corticosteroids irrespective of route of administration have varied from $18 \%$ to $90 \%$ (6), and though numerous publications over the years have described administration of lumbar epidural steroid injections by various routes (6-22). Most of the analyses $(7,8,11-20)$ have failed to separate the three approaches. Bogduk et al (9), and Manchikanti et al (6) evaluated the effectiveness of caudal epidural steroid injections separate from transforaminal and interlaminar epidural injections. These investigators $(6,9)$ have shown caudal epidural steroids overall to be superior to interlaminar epidural injections and equal to transforaminal epidural injections. Further, there has been only one study which compared the effectiveness of the three routes of epidural steroid injections in chronic low back pain, namely the caudal, interlaminar and transforaminal (23). Another 
study (24) compared caudal and interlaminar epidurals, showing no significant difference between the two approaches.

\section{HISTORICAL CONSIDERATIONS}

Historical development of caudal epidural injections was contentious and hasty. Jean-Anthanase Sicard (25), a radiologist, was the first to describe injection of dilute solutions of cocaine through the sacral hiatus (the caudal route) into the epidural space in 1901, to treat patients suffering from severe, intractable sciatic pain or lumbago. One week later but independently, in 1901, Cathelin (26), urologist, described caudal administration of local anesthetic for surgical procedures and also injection of cocaine for relief of pain due to inoperable carcinoma of the rectum. In the same year, Pasquier and Leri (27), also independently, reported the use of caudal epidural injection for the relief of sciatic pain. The extension of this technique to the treatment of sciatica is attributed to Caussade and Queste (28) in 1909, Viner (29) in 1925, Evans (30) in 1930, Cyriax $(31,32)$ from 1937 to the 1970s, and Brown (33) in 1960. Lumbar epidural anesthesia was described by Pages in Spain in 1921 (34). Ever since this description of lumbar epidural anesthesia, the glory of caudal epidural blockade not only ended, but also suffered from comparison with interlaminar neural blockade, considered as more favorable in anesthesia.

The development of caudal epidural administration of local anesthetic technique also contributed to the development of contrast radiology (35). Sicard (25) with Forestier (36), first examined the epidural space in 1921. Sicard and Forestier (36-39), in a series of publications starting with examination of the epidural space with contrast (36), described examination of the subarachnoid space (37) and the technique of myelography (38).

Initial use of corticosteroids into the epidural space was through sacral nerve roots as reported by Robechhi and Capra (40) and Lievre et al (41), in 1952 and 1953. Cappio (42), in 1957, reviewed the literature and reported good results in $67 \%$ of 80 cases with caudal administration of steroids. The literature was initially dominated by reports in Europe (9). The first meaningful American study was published in 1961 by Goebert et al (43), addressing 113 patients, 86 of whom received caudal epidural injections, with $72 \%$ obtaining greater than $60 \%$ relief of their pain. Since then the literature has been replete with numerous retrospective studies, case reports, and meta analyses; some randomized clinical trials; one study comparing three routes of administration of lumbar epidural steroids, and an additional study comparing interlaminar and caudal routes in managing chronic low back pain $(23,44,45-65)$. The chronology of the evolution of caudal epidural injections is described in Table 1.

\section{PATHOPHYSIOLOGIC CONSIDERATIONS}

Tissues in the lower back capable of transmitting pain in-

Table 1. Chronology of evolution of caudal epidural injections

1901 - Sicard (25)

First reports of caudal local anesthetic

1901 - Cathelin (26)

Caudal local anesthetic for surgery and relief of rectal pain

1901 - Pasquier and Leri (27)

First epidural for sciatica

1909 - Caussade and Queste (28)

Cures of sciatica with epidural

1921 - Sicard and Forestier (36)

First epidurogram

1928 - Viner (29)

Routine use of caudal local anesthetic for sciata

1930 - Evans (30)

Large volume caudal injections

1951 - Bresgen (105)

Considered pain provocation with caudal to indicate organic origin

1953 - Cappio - (42)

Use of caudal epidural steroids

1960 - Brown (33)

Pressure caudal anesthesia

1960s - Cyriax $(31,32)$

High volume caudal anesthesia

1961 - Goebert et al (43)

First US report 
clude the disc, nerve root dura, muscle, ligament, fascia, and facet joint (66). Pain from lumbar disc herniation can arise from nerve root compression and stimulation of nociceptors in the anulus or posterior longitudinal ligament. Mixter and Barr in 1934 described intervertebral disc herniation, which led many practitioners to assume that intervertebral disc herniation is the most common cause of back problems (5). However, modern evidence implicates intervertebral disc herniation in only a small percentage of back complaints $(6,67-72)$. Thus, a simple ideological explanation of compression or mass effect lacks practical application. Several studies evaluating the progress of disc herniation also have shown that, even though the resolution of symptoms tends to be associated diminution of the size of the disc herniations, it is not always the case, as compression may continue in spite of resolution of the symptomatology (72-76). It is also well described in many studies (77-80) that asymptomatic individuals present with disc herniations that are evident on computerized tomographic axial scan or on magnetic resonance imaging scan. A multitude of mechanisms have been proposed to explain radicular pain, which include partial axonal damage, neuroma formation, and focal demyelination (81); intraneural edema (82-85); and impaired microcirculation $(84,85)$. Further, the theory of chemical irritation and inflammation around the discs and nerve roots is also considered a major contributor in conjunction with or without mechanical factors.

\section{RATIONALE}

The philosophy of epidural steroid injections is based on the premise that the corticosteroid delivered into the epidural space attains higher local concentrations over an inflamed nerve root and will be more effective than a steroid administered either orally or by intramuscular injection $(9$, $44,86,87)$. Target site concentration of steroids depends on multiple injection variables, including the route of administration. Transforaminal epidural injections are considered as target specific (86-88). In contrast, interlaminar epidural injections, as well as caudal epidural injections, are considered nonspecific. Steroids may be prevented from migrating from the posterior epidural space to the anterior or ventral epidural space by the presence of epidural ligaments or scar tissue, either with caudal or interlaminar administration. Interlaminar lumbar epidural injections are alleged by some to be superior and target specific to caudal epidural injections. However, the extradural placement of the needle, which may go unrecognized without fluoroscopic guidance, is of importance $(6,9,44$, $89,90)$. Other disadvantages of the interlaminar approach include erroneous placement of the needle, which may miss the targeted interspace without fluoroscopic guidance (90, 91); preferential cranial flow of the solution in the epidural space $(91,92)$; deviation of the needle to the nondependent side; difficulty entering the epidural space and delivery of injectate below L5, for S1 nerve root involvement; potential risk of dural puncture and postlumbar puncture headache; and, finally, the rare, but serious, risk of spinal cord trauma $(93,94)$.

Similar to interlaminar epidural injections, transforaminal epidural injections also have some disadvantages; however, they are much less frequent and significant in terms of maintaining the target delivery of corticosteroid (8688). These disadvantages of transforaminal epidurals include intravascular penetration of the needle, neural penetration, and spinal cord trauma.

Caudal epidurals have been described as very effective, with easy entry without dural puncture. However, the criticism has been made that the caudal epidural injection necessitates injection of a substantial volume of fluid, which essentially dilutes the corticosteroid concentration to the target site $(6,9,95)$. Further disadvantages are intravascular and extravascular placement of the needle (95-107). Additionally, it has been described that corticosteroid administered caudally does not reach the presumed target site, (the ventral epidural space in front of the dural sac and behind the disc). Studies have shown that in normal volunteers the transforaminal approach showed good target specific ventral flow (108). However, following interlaminar epidural injection of contrast, the flow was predominantly dorsal, far removed from the usual site of inflammation (108). No such studies have been conducted evaluating the distribution of contrast following caudal epidural injection. Various factors leading to the failure of epidural corticosteroid injections are described by Saal and Saal (109).

The rationale for epidural steroids focused on strong antiinflammatory effects of corticosteroids (9). Propositions were made that sciatica might be directly associated with inflammation $(9,47,110-122)$. The first direct evidence of inflammation in patients with radiculopathy was documented in 1981 (123). Ryan and Taylor (123), by examining samples of CSF during administration of intrathecal and epidural injections, observed that inflammation was a critical component of radicular pain. They also reported that intraspinal steroids were likely to act best when this inflammation was still acute, before the pathology had progressed to nerve root fibrosis or axonal death. Conse- 
quently, they classified patients with lumbar radiculopathy into two categories, namely, compressive and irritative radiculopathy.

The present clinical rationale for steroid usage in caudal epidurals is primarily based on the benefits, which include pain relief outlasting by hours, days, and sometimes weeks, the pharmacological action of steroids and local anesthetics. However, appropriate explanations for such benefits continue to lack scientific validity. Additional explanations include alteration or interruption of nociceptive input, reflex mechanism of the afferent limb, self-sustaining activity of the neuronal pools in the neuraxis, and the pattern of central neural activities by neural blockade, including caudal epidural steroids (124). The basis for these explanations is twofold. First, it is postulated that corticosteroids reduce inflammation either by inhibiting the synthesis or release of a number of proinflammatory substances or by causing a reversible local anesthetic effect (125-139). Second, administration of epidural solutions clears or dilutes the chemical irritants. Corticosteroids are postulated to exert their effect by multiple modes, including membrane stabilization, inhibition of neural peptide synthesis or action, blockade of phoslolipase $\mathrm{A}_{2}$ activity, prolonged suppression of ongoing neuronal discharge, and suppression of sensitization of dorsal horn neurons (140, 141).

Inflammatory reactions between the nucleus pulposus and nerve roots have been suggested as playing an important role in disc herniation with sciatica. However, the pathogenic mechanisms linking herniated nucleus pulposus, nerve root injury, and sciatica are not clearly demonstrated (109-123, 142-157). It has been postulated that sensory neurons in the associated dorsal root ganglia are affected by the chemical injury, and the behavioral pattern changes observed in the irritating nerve root model are caused in part by a high level of phospholipase $\mathrm{A}_{2}$ activity initiated by inflammation (134). The mechanism of action of epidural steroid injection in this model was inhibition of phospholipase $\mathrm{A}_{2}$ activity (134). Thus, these investigations (130, 133-135, 158) provide clinical support for use of epidural steroid injections in managing chemical irritation and inflammation around the discs and nerve roots. Experimental evidence shows epidural application of the nucleus pulposus to induce pronounced morphologic and functional changes in the nerve roots (144). Intravenous (IV) methylprednisolone was shown to reduce the nerve root injury secondary to nucleus pulposus in the epidural space (130). Epidural injection of betamethasone in a model of lumbar radiculopathy showed a significant effect on thermal hy- peralgesia (133). In an experimental study in the rabbit, it was shown that lipopolysaccharide accelerated the process of herniated intervertebral disk resorption, whereas high dose steroid suppressed the process (135). Lee et al (134) evaluated the role of steroids and their effects on phospholipase $\mathrm{A}_{2}$ in an animal model of radiculopathy, showing a steady reduction in phospholipase $\mathrm{A}_{2}$. Byrod et al (139) also showed that methylprednisolone reduces the early vascular permeability increase in spinal nerve roots induced by epidural nucleus pulposus application in the pig experimental model.

However, the basis for the relief obtained from epidural Sarapin, as well as other agents at present is not known.

\section{CLINICAL EFFECTIVENESS}

The literature is replete with numerous opinions, which are not only contradictory, but also confusing, on the clinical effectiveness of epidural steroid injections in general and caudal epidural steroids in particular. Various reports of clinical effectiveness include randomized clinical trials with or without blinding; prospective trials; retrospective studies, either randomized or nonrandomized; case reports; and, finally, meta analyses. Unfortunately, clinical trials of the efficacy of commonly used interventions in low back pain reviewed by Koes et al (159), Van Tulder et al (160, $161)$ and others $(6,7,10-19,162,163)$ led to the conclusion that the methodological quality in these studies was disappointingly low. Further, most of the studies of epidural steroid injections have been performed by multiple specialty groups (rarely including interventional pain specialists) and without fluoroscopy. Epidural administration of steroids is ideally performed under fluoroscopic guidance (164).

Randomized, double-blinded studies are considered to represent the best available evidence. Thus, clinical efficacy of any intervention presumably is ideally measured by randomized, double-blind trials. Many stumbling blocks including the issues of ethics, feasibility, cost and reliability, pose frequently insurmountable challenges to randomized, double-blind trials in interventional pain medicine (6). In addition, the value of the so-called "gold standard" of a randomized, double-blind trial has been questioned. Benson and Hartz (165) outlined several advantages of observational studies over randomized, controlled trials including lower costs, greater timeliness, and a broader range of patients. They compared the results of observational studies with those of randomized, controlled trials. They concluded that in most cases, the estimates of the 
Table 2. Cumulative significant relief (>50\%) in weeks by number of procedures

\begin{tabular}{|c|c|c|c|c|}
\hline $\begin{array}{l}\text { No. of } \\
\text { procedures }\end{array}$ & $\begin{array}{l}\text { Blind interlaminar } \\
(\text { mean + SEM })\end{array}$ & $\begin{array}{l}\text { Fluoroscopic caudal } \\
\text { (mean + SEM) }\end{array}$ & $\begin{array}{l}\text { Fluoroscopic transforaminal } \\
\text { (mean + SEM) }\end{array}$ & F-ratio (P value) \\
\hline 1 & $1.1+0.04(69)$ & $3.0+1.27(66)$ & $1.6+0.17(68)$ & $1.6482(0.1950)$ \\
\hline 2 & $3.1+0.13(69)$ & $5.2+0.74(66)$ & $8.4^{* \#+1.74(68)}$ & $5.9386(0.0031)$ \\
\hline 3 & $6.7+0.37(60)$ & $10.3+0.96(56)$ & $20.6 * \#+4.20(56)$ & $8.6606(0.0003)$ \\
\hline 4 & $11.3+0.61(48)$ & $18.4+1.71(47)$ & $24.2^{*}+3.57(42)$ & $8.6922(0.0003)$ \\
\hline 5 & $15.5+1.02(33)$ & $24.7+2.35(38)$ & $32.7 * \#+4.05(33)$ & $9.4497(0.0002)$ \\
\hline
\end{tabular}

treatment effects from observational studies and randomized, controlled trials were similar. Concato et al (166) in evaluating various types of clinical evaluations concluded that the average results of observational studies were remarkably similar to those of randomized, controlled trials and that the results of well-designed observational studies do not systematically overestimate the magnitude of the effects of treatment as compared with those in randomized, controlled trials on the same topic. Bogduk et al (9), in the report prepared by the working party set up in March 1991 by the Healthcare Committee of the National Health and Medical Research Council of Australia to examine the value of epidural use of steroids in the management of back pain, concluded that all reports on the use of caudal epidural steroids have been favorable with respect to benefits.

The first uncontrolled but significant study by Goebert et al (43) evaluated a series of 121 injections administered to 113 patients with radicular pain, of which 94 were caudal epidural injections. Epidural injections of $30 \mathrm{~mL}$ of $1 \%$ procaine combined with $125 \mathrm{mg}$ of hydrocortisone acetate (the intra-articular suspension) were employed usually for 3 consecutive or alternate days. They reported overall good results in $72 \%$ of the patients, with poor results in $17 \%$. They reported good results in only $50 \%$ of patients with suspected disc protrusion, while $76 \%$ of the patients with radiculopathy following laminectomy and $86 \%$ of the patients with radiculopathy from other causes showed good results. In another study from the same center, Gardner et al (46) reported that 137 out of $239(53 \%)$ patients with sciatica reported $60 \%$ to $100 \%$ pain relief for a minimum period of 3 months. Lindholm and Salenius (56) reported good results at 2 to 6 months in 10 out of 13 patients with back pain attributed to disc degeneration, in 12 out of 14 patients with nerve root compression, and in 3 of 5 patients with presumed ligament strain. Mount (49) studied
545 patients suffering from nonspecific lumbar intervertebral disc syndrome, reporting complete relief in 292 patients and greater than $85 \%$ relief in 104 patients. Sharma (52) reported results in 201 patients suffering with lumbago, sciatica, backache with sciatica, and other conditions with favorable pain relief in $56 \%$ of the patients.

Ciocon et al (63) studied the efficacy of caudal epidural blocks for elderly patients with lumbar canal stenosis, showing significant pain reduction for up to 10 months, with satisfactory relief in $90 \%$ of patients.

Manchikanti et al (23), in evaluating the effectiveness of caudal epidural steroid injections under fluoroscopic visualization, showed significant improvement that was better than that of blind lumbar interlaminar epidural injections. In this retrospective but consecutive evaluation, patients were divided into three groups with 75 patients in each group. Group I received blind lumbar epidural steroid injections, Group II received caudal epidural steroid injections under fluoroscopy, and Group III received transforaminal epidural corticosteroid injections under fluoroscopic visualization. Cumulative significant relief, which was defined as greater than 50\% relief, was reported following three procedures for a mean of $10.3+0.96$ weeks in patients receiving caudal epidurals, in contrast to $6.7+$ 0.37 weeks in patients receiving blind lumbar epidural steroid injections (Table 2). However, the response to caudal epidural steroids was inferior to transforaminal epidural corticosteroid injections.

Most meta analyses by various authors have combined evaluations of all types of epidural injections. In developing guidelines for interventional techniques, Manchikanti et al (6) evaluated the effectiveness of epidural steroid injections separately, dividing them into caudal, interlaminar 
and transforaminal. They showed that, of the six controlled trials, five showed positive results. Bogduk et al (9) concluded that caudal epidural steroids were clinically effective with a favorable profile. Koes et al $(10,12)$ reviewed the role of epidural steroid injections, including 12 trials of lumbar and caudal epidural steroid injections in 1995 and 15 trials in 1999. They reported positive results in 6 of the 12 trials in 1995 and 8 of the 15 trials in 1999. However, the separation of lumbar and caudal epidural steroid injections showed that, of the 5 studies for caudal epidural steroid injections in 1995, 4 were positive; whereas, of 15 trials in 1999, 5 included caudal epidural steroids, once again the same studies as the previous study, with 4 being positive. Watts and Silagy (15) in 1995 performed a meta analysis of the available data and defined efficacy in terms of pain relief (at least $75 \%$ improvement) in the shortterm (60 days) and in the long-term (1-year). They concluded that epidural steroid injections increased the odds ratio of pain relief to 2.61 in the short-term and 1.87 in the long-term. McQuay and Moore (16) in 1988 reviewed the literature and concluded that epidural corticosteroid injections are effective for back pain and sciatica. However, the first systematic review of the effectiveness of epidural steroid injections by Kepes and Duncalf in 1985 (7) concluded that the rationale for epidural steroids was not proven. Benzon (8), a year later utilizing the same studies, concluded that mechanical causes of low back pain, especially those accompanied by signs of nerve root irritation, may respond to epidural steroid injections. Unfortunately, Kepes and Duncalf (7) also included studies on systemic steroids. Benzon (13), and Benzon and Molley (14) considered the role of epidural steroid injections controversial but recommended the continued use of epidural steroid injections as part of the overall management of patients with acute radicular pain, herniated disc, or new radiculopathy superimposed on chronic back pain. Nelements et al (17) evaluated the effectiveness of injection therapy, lumping together all types of epidural steroid injections, trigger point injections, facet joint blocks, and intradiscal steroids. In addition, they also failed to include all the relevant literature, and the conclusions were flawed. Vroomen et al (18) evaluated conservative treatment of sciatica, including epidural steroids, including a total of four studies which involved only one caudal.

Among the prospective but nonrandomized trials response has been encouraging. Yates (53) evaluated 20 consecutive patients, allocating them into four groups. He concluded that addition of steroid to any base mixture resulted in greater improvement. Waldman (57) evaluated the effectiveness of caudal epidural steroids in 53 patients with radicular pain distribution anatomically correlating with documented disc herniation and nerve root impingement, with administration of up to four caudal steroid injections. Results showed that combined visual analog scale and verbal analog scores for all patients were reduced $63 \%$ at 6 weeks, $67 \%$ at 3 months, and $71 \%$ at 6 months. White et al (44), in a prospective evaluation of 304 consecutive patients with low back pain, showed a short-term success of approximately $87 \%$, with only $24 \%$ of the patients showing significant relief at 6 months without psychologic overlay and in $34 \%$ of the patients presenting with acute pain. Swerdlow and Sayle-Creer (58) studied 325 patients suffering from lumbosciatic syndrome, showing in a total of $67 \%$ of the patients in the methylprednisolone group significant improvement in the chronic group, whereas it was $72 \%$ in the acute group, and $61 \%$ in the patients with recurrent pain.

Manchikanti et al (65) evaluated effectiveness of caudal epidural injections in discogram-positive and negative chronic low back pain patients, including 45 patients with negative provocative discography, and 17 patients with positive provocative discography. Sixty-nine percent of the patients in the negative discography group and $65 \%$ of the patients in the positive discography group were in the successful category. Patients in the successful category responded with 1 to 3 injections, with cumulative relief of greater than $50 \%$ in $100 \%$ of the patients at 1 month; at 3 months, negative provocative discography declined to $86 \%$; and at 6 months, both positive and negative provocative discography groups declined to $60 \%$ and $64 \%$ as shown in Fig. 1. As shown in Table 3, comparison of significant relief greater than $50 \%$ with each injection was significantly better in the negative provocative discography group with injections 5, 6, 7 and 8 compared to the positive provocative discography group. Comparison of overall health

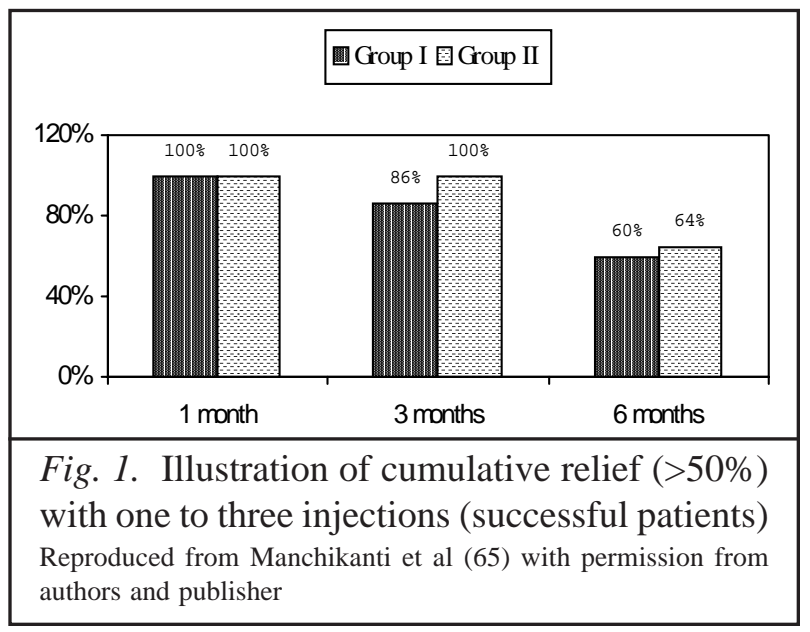


Table 3. Comparison of significant relief (>50\%) with each injection by group in weeks, in successful category

\begin{tabular}{|c|c|c|c|c|}
\hline \multirow[t]{2}{*}{$\begin{array}{l}\text { Injection } \\
\text { Number }\end{array}$} & \multicolumn{2}{|c|}{$\begin{array}{c}\text { Group I } \\
\text { Negative Discography }\end{array}$} & \multicolumn{2}{|c|}{$\begin{array}{c}\text { Group II } \\
\text { Positive Discography }\end{array}$} \\
\hline & Mean + SEM & Range & Mean + SEM & Range \\
\hline One & $8.5+0.43(31)$ & $4-13$ & $13.3+6.03(11)$ & $3-73$ \\
\hline Two & $8.7+0.51(31)$ & $3-13$ & $8.7+1.02(10)$ & $4-13$ \\
\hline Three & $9.8+0.51(25)$ & $4-13$ & $9.5+1.20(8)$ & $4-13$ \\
\hline Four & $12.4+1.80(24)$ & $4-13$ & $9.4+1.51(8)$ & $0-13$ \\
\hline Five & $11.3^{*}+0.41(19)$ & $9-13$ & $8.7+1.67(6)$ & $1-13$ \\
\hline Six & $10.7^{*}+0.48(12)$ & $9-13$ & $5.0+2.92(4)$ & $0-11$ \\
\hline Seven & $12.1 *+0.49(11)$ & $9-13$ & $6.0+3.00(3)$ & $0-9$ \\
\hline Eight & $11.8^{*}+0.65(6)$ & $9-13$ & $7.5+1.5(2)$ & $6-9$ \\
\hline Nine & $11.0+2.00(2)$ & $9-13$ & $5.5+3.50(2)$ & $2-9$ \\
\hline Ten & - & - & $9(1)$ & 9 \\
\hline Average & $10.2+0.33$ & $3-13$ & $9.3+1.28$ & $0-73$ \\
\hline
\end{tabular}

status, psychological status, and narcotic intake showed significant improvement in the successful category group compared to failed category group in comparison to pretreatment and post-treatment. In addition, there was also significant improvement shown in terms of employment status with a significant proportion of patients (27\%) being employed during the treatment and at the end of the treatment with no significant change noted in the employment category in failed categories in both groups (Fig. 2).

Thus far, the extensive literature available on caudal epi-

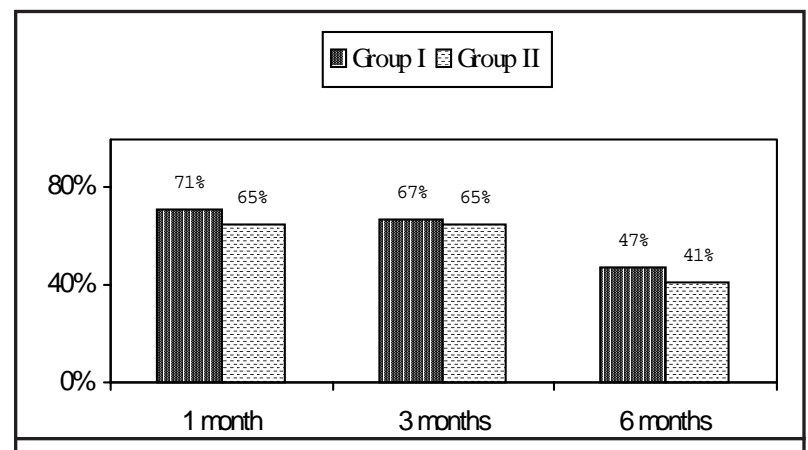

Fig. 2. Illustration of cumulative relief ( $>50 \%)$ with one to three injections (all patients)

Reproduced from Manchikanti et al (65) with permission from authors and publisher dural steroid injections includes eight randomized, controlled trials with or without blinding $(48,50,51,55,60-$ $62,64)$. Breivik et al (51), in a prospective, randomized, crossover study, evaluated 35 patients with chronic low back pain, allocated to treatment with up to three caudal epidural injections of bupivacaine and methylprednisolone or bupivacaine and normal saline at weekly intervals. During initial therapy $56 \%$ of patients receiving methylprednisolone experienced significant relief, compared to $26 \%$ with bupivacaine with saline. While $50 \%$ of the patients treated with steroids returned to work, $20 \%$ of the patients treated with bupivacaine returned to work. Bush and Hillier (60) in a double-blind, randomized study of 23 patients with lumbar radicular pain, demonstrated significantly greater pain relief and mobility with a significantly improved quality of life following triamcinolone injection. In contrast to the above studies, Beliveau (50) found no difference in pain relief between 24 patients treated with caudal injections of $40 \mathrm{~mL}$ of $1 \%$ procaine and $80 \mathrm{mg}$ (2 $\mathrm{mL}$ ) of methylprednisolone, and an equal number of patients treated with $42 \mathrm{~mL}$ of procaine alone. One to three months later they saw complete relief in $42 \%$ of the patients in the steroid group, and in $29 \%$ in the normal saline group. This study demonstrated the efficacy of caudal epidural injections in sciatica with or without steroids. Matthews et al (55) compared the responses of patients 
treated with caudal epidural injections of bupivacaine and methylprednisolone or a control injection of $2 \mathrm{~mL}$ of lignocaine over the sacral hiatus. While, at assessment after 1 month, there was no significant difference between the two groups, at 3 months, the treated group was reported to be significantly more pain free. Czarski (48) evaluated the use of caudal epidural injections, comparing Novocaine ${ }^{\circledR}$, hydrocortisone and procaine hydrochloride alone in the treatment of patients with prolapsed lumbar intervertebral disc, with 60 patients in the procaine hydrochloride group and 123 patients in the procaine hydrochloride and hydrocortisone group. He demonstrated statistically significant and clinically significant differences in outcomes comparing the use of caudal epidural injections.

Manchikanti et al (64) studied 65 patients, with 15 patients in a control group (Group I), 22 patients in Group II receiving caudal epidural with local anesthetic and Sarapin, and Group III patients treated with local anesthetic and betamethasone. They showed significant improvement in the treatment group in terms of pain relief, functional status, psychological status, and employment status; narcotic intake also improved with one to three injections. Improvement was seen in $97 \%$ of the patients at 1 month, in $57 \%$ at 3 months, and in $17 \%$ at 6 months. Cumulative relief greater than $50 \%$ with 1 to 12 injections showed greater than $50 \%$ relief in $86 \%$ of the patients at 6 months and in $67 \%$ of the patients at 1 year. The study also showed that apart from the clinical effectiveness, the treatments were cost effective, with cost for 1 year improvement of quality of life on average for both groups at $\$ 2,550$. Significant decrease was seen in heavy narcotic intake during posttreatment in treatment groups. Increase in employment was seen in both treatment groups. Fig. 3 illustrates the cumulative relief (greater than 50\%) with 1 to 3 injections.

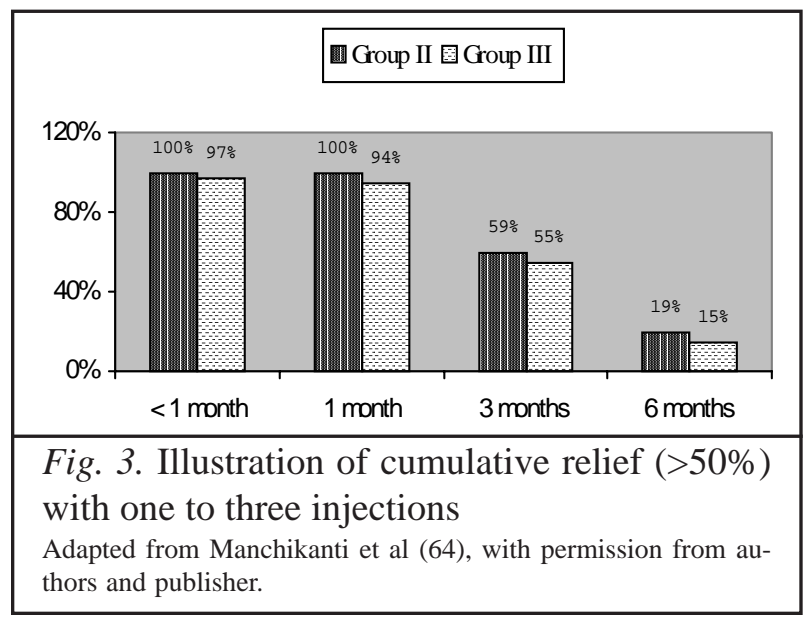

There also have been two publications reporting the use of forceful caudal epidural injections in managing lumbosciatic pain with postoperative lumbar epidural fibrosis or failed lumbar laminectomy syndrome $(106,107)$. Both studies (a randomized trial (106), and a controlled, non-randomized trial) concluded that forceful epidural corticosteroid injections were better.

\section{INDICATIONS}

Caudal epidural steroid injections are indicated in patients with chronic low back pain who have failed to respond to conservative modalities of treatments. The procedure should always be performed under fluoroscopy. Patients should present with a strong radicular component or discogenic pain or at least they must not have facet joint pain or sacroiliac joint pain. Patients with combined pain generators with discogenic pain as well as facet joint pain may also receive caudal epidural steroid injections. While caudal epidural steroid injections may be performed for any type of low back pain with or without lower extremity pain nonresponsive to conservative modalities of treatments, they are properly indicated in patients negative for facet joint pain or patients who have a combination of discogenic component with facet joint pain. Caudal epidural steroids are the preferred modality of treatment for sacral involvement, in postsurgical patients, and in patients with bilateral involvement or multilevel involvement for which transforaminal epidurals will require multiple procedures at multiple levels.

In the past, a multitude of investigators has attempted to identify predictors of outcome of epidural injections, as well as facet joint injections. However, these attempts have been proven to be futile; hence, no such recommendations are made in this review. Various contraindications include the patient's inability to be in the prone position, contraindications for fluoroscopy, local or systemic infection, abnormalities of the sacrum, and allergy to any of the drugs used.

\section{COMPLICATIONS}

Caudal epidural injections are associated with occasional, but common and rarely worrisome, complications. These are related to dural puncture, spinal cord compression, infection, and toxicity of steroids $(6,140,141,167,168)$.

Early reports of caudal epidural injections showed that large volumes of injectate were utilized. Evans (30) used up to $140 \mathrm{~mL}$, with exceedingly rare occurrences of complica- 
tions. Cyriax $(31,32)$ used high-volume injections in over 20,000 patients, with 50,000 injections utilizing $50 \mathrm{~mL}$ of procaine, and reported no major disasters and only five misfortunes, with one case of hypersensitivity, two cases of temporary paraplegia of the lower half of the body, and two cases of chemical meningitis; all patients recovered without lasting harm. Bogduk et al (39) reported that injected volumes tend to be variable from 10 to $64 \mathrm{~mL}$ for caudal injection of steroids and also stated that a volume of $10 \mathrm{~mL}$ should be used to reach the L5 segment and 15 $\mathrm{mL}$ should be used to reach the $\mathrm{L} 4$ segment. Complications have been reported with injections of high volumes into the epidural space, with increasing intraarticular pressure with retinal hemorrhage. Manchikanti et al (95) in a prospective study attempted to correlate optimal dose of injectate with filling defects observed on an epidurogram. They concluded that increasing the volume of injectate greater than $10 \mathrm{~mL}$ does not seem to improve the filling pattern.

Spinal cord compression following rapid injections into the epidural space, which may cause large increases in intraspinal pressure with a risk of cerebral hemorrhage, visual disturbances, headache, and compromise of spinal cord blood flow, has been mentioned. However, the only complication reported following epidural injection has been vision loss. Kushner and Olson (169) evaluated patients who complained of visual-field defects or blurred vision after receiving epidural steroid injections and concluded that retinal hemorrhage is uncommon but significant, and a previously unemphasized complication of epidural steroid injections in general. Retinal hemorrhages mainly have been attributed to rapid epidural injections of high volumes, causing a sudden increase in intracranial pressure, resulting in the increase of retinal venous pressure (169175).

Epidural infection following this procedure is an extremely rare, but distinct, possibility due to the procedure itself, location of needle placement, and potential immunosuppression secondary to steroid injection. Sampath and Rigamonti (176), in a review of epidemiology, diagnosis, and treatment of spinal epidural abscess, noted that spinal nerve block was responsible for $7 \%$ of the patients, whereas a multitude of predisposing factors included IV drug use, diabetes neuritis, multiple medical illnesses, trauma, prior spinal surgery, morbid obesity, HIV disease, and end-stage renal disease, in descending order of frequency. Wang et al (177), in a 1-year study of the incidence of spinal epidural abscess after epidural analgesia, reported nine cases of epidural abscess formation from a total of 17,372 epidural catheters. Rathmell et al (178) noted that epidural abscess formation is an uncommon but devastating complication that has been associated not only with continuous epidural analgesia (179) but also with single epidural injections (180). They also postulated that epidural abscess most often arises in association with systemic infection, but it also rarely occurs following epidural analgesia (178).

Direct trauma to the spinal cord following lumbar epidural injections has been rarely reported, with disastrous complications $(93,94)$. However, none of the case reports involved caudal epidural injections. The incidents of intravascular placement of the needle during caudal epidural injections documented by contrast-enhanced fluoroscopic imaging and negative blood aspiration has varied from $5 \%$ to $11 \%(44,95-98)$.

Spinal cord or epidural hematoma is a potential complication; however, no cases have been reported with caudal epidural injections (178-183), so the actual incidence, if any, is not known. The incidence with epidural injections cited in the literature is estimated to be less than 1 in 150,000 epidurals. Epidural hematomas have been reported following epidural analgesia in a patient with peripheral vascular disease receiving unfractionated heparin for thromboprophylaxis and paraplegia after epidural anesthesia

Accidental dural puncture and subarachnoid injection have been described with epidural injections, even though there are no specific descriptions relating to caudal epidural injections. Transient neurologic symptoms after epidural analgesia have been reported, which included cauda equina syndrome (183-194). Horlocker and Wedel (190) reported a $0.2 \%$ to $2.9 \%$ cardiac arrest rate, $0.2 \%$ to $1.2 \%$ death rate, $0.4 \%$ to $3.6 \%$ neurological injury rate, 0.5 to $3.8 \%$ radiculopathy rate, $0 \%$ to $1.2 \%$ incidence of cauda equina syndrome and $0 \%$ to $1.8 \%$ incidence of paraplegia after reviewing 30,413 epidurals. They also reported anterior spinal artery syndrome's leading to spinal cord ischemia, resulting in flaccid paralysis of the lower extremities (190195).

Other side effects are related to the administration of steroids and are generally attributed to the chemistry or pharmacology of the steroids. The safety of steroids and preservatives at epidural therapeutic doses has been demonstrated in both clinical and experimental studies $(140,141$, 196-203). The major theoretical complications of corticosteroid administration include arachnoiditis, suppression of the pituitary-adrenal axis, hypocorticism, Cushing's syn- 
drome, osteoporosis, avascular necrosis of bone, steroid myopathy, weight gain, fluid retention, and hyperglycemia $(140,141,204-214)$. Other potential complications include hypertension, hypokalemia, epidural lipomatosis, subcapsular cataract formation, insomnia, mood swings, psychosis, facial flushing, headache, gastrointestinal disturbances, and menstrual disturbances $(140,141)$. Manchikanti et al (204) evaluated the effect of neuraxial steroids on weight and bone mass density (BMD) prospectively. They concluded that low-dose neuraxial steroids are safe in patients with chronic pain who have failed to respond to conservative modalities of treatments with a favorable risk-benefit ratio, without any deleterious effects either on body weight or BMD. Cousins (215) reported that an additional potential complication of administration of depo-corticosteroids related to inadvertent intravascular administration, producing occlusion of small end arteries which resulted in visual defects in one case (216) and hearing loss in another case involving suboccipital nerve block. Abram (217) also acknowledged the potential for harm from occlusion of small-end arteries by steroid suspensions. Abram (217) felt that prednisolone acetate tends to form aggregates of the steroid material when mixed with local anesthetic and may pose more of a risk for this problem than other depo-steroids. However, preparations of either methylprednisolone or triamcinolone could produce devastating consequences if injected into a spinal artery. In this aspect, betamethasone appears to be the safest, as it is most soluble with local anesthetic.

Botwin et al (107) studied complications of fluoroscopically guided caudal epidural injections. They showed that in 139 patients, with 257 injections over a 12-month period, complications per injection included, in descending order of frequency, insomnia (4.7\%), transient nonpositional headaches $(3.5 \%)$, increased back pain (3.1\%), facial flushing (2.3\%), vasovagal reactions $(0.8 \%)$, nausea $(0.8 \%)$, and increased leg pain $(0.4 \%)$.

\section{CONCLUSION}

Caudal epidural steroid injections are simple, safe, and effective techniques for managing chronic low back pain. Much of the confusion surrounding caudal epidural steroid injections is based on a lack of understanding as well as a lack of appropriate evaluation of their effectiveness, along with the usual overemphasis on biopsychosocial problems and inappropriate selection of patients. Considering the cumulative evidence available in the literature, caudal epidural steroid injections are as effective as numerous other interventions applied in managing chronic low back pain, if not superior.

Even though caudal epidural steroid injections are effective, safe and simple techniques in managing chronic low back pain, caution must be exercised, as there are significant risks associated with this technique. An interventional pain physician needs to individualize the choice of treatment to each patient and personal experience. Caudal epidural steroid injections should only be performed when medically necessary, based on the progress of the patients, to provide cost-effective care without creative billing. They are best performed under fluoroscopic visualization.

\section{REFERENCES}

1. Cotugno DFA. De Ischiade nervosa commentarius. Naples, Fratres Simonios, 1764.

2. Putti V. New conceptions in the pathogenesis of sciatic pain. Lancet 1927; 2:53-60.

3. Mixter WJ. Historical perspective. Spine 1998; 23:2363-2366.

4. Kocher T. die Verletzungen der Wirbelsaule zugleich als Beitrag zur Physiologie des menschlichen Ruckenmarks. Mitt az Grenzgeb d Med u Chir 1896; 1:415-480.

5. Mixter WJ, Barr JS. Rupture of the intervertebral disc with involvement of the spinal canal. $N$ Eng $J$ Med 1934; 211:210-215.

6. Manchikanti L, Singh V, Kloth D et al. Interventional techniques in the management of chronic pain: Part 2.0. Pain Physician 2001:4:24-96.

7. Kepes ER, Duncalf D. Treatment of backache with spinal injections of local anesthetics, spinal and systemic steroids. Pain 1985; 22:33-47.

8. Benzon HT. Epidural steroid injections for low back pain and lumbosacral radiculography. Pain 1986; 24:277.

9. Bogduk N, Christophidis N, Cherry D et al. Epidural Use of Steroids in the Management of Back Pain. Report of Working Party on Epidural Use of Steroids in the Management of Back Pain. National Health and Medical Research Council. Canberra, Commonwealth of Australia, 1994, pp 1-76.

10. Koes BW, Scholten RJPM, Mens JMA et al. Efficacy of epidural steroid injections for low back pain and sciatica: A systematic review of randomized clinical trials. Pain 1995; 63:279-288.

11. Bogduk N. Epidural steroids for low back pain and sciatica. Pain Digest 1999; 9:226-227.

12. Koes BW, Scholten R, Mens JMA et al. Epidural steroid injections for low back pain and sciatica. An updated systematic review of randomized clinical trials. Pain Digest 1999; 9:241-247.

13. Benzon HT. Epidural steroid injections. Pain Digest 1992; 1:271-280. 
14. Benzon HT, Molly RE. Outcomes, efficacy, and compliances from management of low back pain. In Raj PP, Abrams BM, Benzon HT et al (eds). Practical Management of Pain, ed 3, Mosby, Philadelphia, 2000, pp 891-903.

15. Watts RW, Silagy CA. A meta-analysis on the efficacy of epidural corticosteroids in the treatment of sciatica. Anaesth Intens Care 1995; 23:564-569.

16. McQuay HJ, Moore RA. Epidural Corticosteroids for Sciatica. An Evidence-Based Resource for Pain Relief. Oxford University Press, New York, 1998, pp 216-218.

17. Nelemans PJ, deBie RA, deVet HCW. Injection therapy for subacute and chronic benign low back pain. Spine 2001; 26:501-515.

18. Vroomen PC, de Krom MC, Slofstra PD et al. Conservative treatment of sciatica: A systematic review. $J$ Spinal Disord 2000; 13:463-469.

19. Revel M. Value of percutaneous treatments of the lumbar spine in back and nerve root pain. Semin Musculoskelet Radiol 1997; 1:349-354.

20. Curatolo M, Bogduk N. Pharmacologic pain treatment of musculoskeletal disorders: Current perspectives and future prospects. Clin J Pain 2001; 17:25-32.

21. Manchikanti L. The role of neural blockade in the management of chronic low back pain. Pain Digest 1999; 9:166-181.

22. Ogoke BA. Caudal epidural steroid injections. Pain Physician 2000; 3:305-312.

23. Manchikanti L, Pakanati RR, Pampati V. Comparison of three routes of epidural steroid injections in low back pain. Pain Digest 1999; 9:277-285.

24. McGregor AH, Anjarwall NK, Stamback T. Does the method of injection alter the outcome of epidural injections? J of Spinal Disorders 2001; 14:507-510.

25. Sicard MA. Les injections medicamenteuse extraduraqles per voie saracoccygiene. Comptes Renues des Senances de la Societe de Biolgie et de ses Filliales 1901; 53:396-398.

26. Cathelin F. Mode d'action de a cocaine injete daus l'escapte epidural par le procede du canal sacre. Comptes Rendies des Senaces de la Societe de Biologic et de ses Filliales, 1901; 53:452-453.

27. Pasquier NM, Leri D. Injection intra-et extradurales de cocaine a dose minime daus le traitment de la sciatique. Bull Gen Ther 1901; 142:196.

28. Caussade G, Queste P. Traitement de al neuralgie sciatique par la mèthode de Sicard. Résultats favorables même dans les cas chroniues par la cocaïne à doses élevées et répétées à intervalles raproches. Bull Soc Med Hosp Paris 1909; 28:865.

29. Viner N. Intractable sciatica-The sacral epidural injection-An effective method of giving pain relief. Can Med Asso J 1925; 15:630-634.

30. Evans W. Intrasacral epidural injection in the treatment of sciatica. Lancet 1930; 2:1225-1229.
31. Ombregt L, Ter Veer HJ. Treatment of the lumbar spine. In Ombregt L, Bisschop P, Ter Veer HJ et al (eds). A System of Orthopaedic Medicine. WB Saunders, London, 1995, pp 633-688.

32. Cyriax JH. Epidural anesthesia and bedrest in sciatica. Br Med J 1961; 1:20-24.

33. Brown JH. Pressure caudal anesthesia and back manipulation. Northwest Med 1960; 59: 905-909.

34. Pages E. Anesthesia metamerica. Rev Sanid Mil Madr 1921; 11:351-385.

35. Jayson MIV, Menkes CJ. Historical perspective: Jacques Forestier. Spine 1995; 20:111-115.

36. Sicard JA, Forestier J: Methode radiographique d'exploration de la cavite epidurale par le Lipiodol. Rev Neurol 1921; 2:1264.

37. Sicard JA, Forestier J. Exploration radiologique par Phuile iodee. Presse Med 1923; 44:1-28.

38. Sicard JA, Forestier J. Roentgenolic exploration of the central nervous system with iodised oil (Lipiodol). Archives Neur Psych 1926; 16:420-434.

39. Sicard JA, Forestier J. The Use of Lipiodol in Diagnosis and Treatment. Oxford, UK: Oxford Medical Publication, 1932.

40. Robechhi A, Capra R. L'idrocortisone (composto F). Prime esperienze cliniche in campo reumatologico. Minerva Med 1952; 98:1259-1263.

41. Lievre JA, Block-Michel H, Pean G et al. L'hydrocortisone en injection locale. Rev Rhum 1953; 20:310-311.

42. Cappio M. Il trattamento idrocortisonico per via epidurale sacrale delle lombosciatalgie. Reumatismo 1957; 9:60-70.

43. Goebert HW, Jallo SJ, Gardner WJ et al. Painful radiculopathy treated with epidural injections of procaine and hydrocortisone acetate: Results in 113 patients. Anesth Analg 1961; 140:130-134.

44. White AH, Derby R, Wynne G. Epidural injections for the diagnosis and treatment of low-back pain. Spine 1980; 5:78-86.

45. Beyer W. Das zervikale and lumbale Bandscheibensyndrom und seine Behandlung mit NovocainPrednisolon-Injecitonen an die Nervenwurzeln. Munch Med Wschr 1960; 102:1164-1165.

46. Gardner WJ, Goebert HW, Sehgal AD. Intraspinal corticosteroids in the treatment of sciatica. Trans Am Neurol Assoc 1961; 86:214-215.

47. Lindhal O, Rexed B. Histologic changes in spinal nerve roots of operated cases of sciatica. Acta Orthop Scan 1951; 20:215-225.

48. Czarski Z. Leczenie rwy kulszowej wstrzykiwaniem hydrokortyzonu I nowokainy do rozworu krzyzowego. Przeglad Lekarski 1965; 21:511-513.

49. Mount HTR. Epidural injection of hydrocortisone for the management of the acute lumbar disc protrusion. In Morley TP (ed). Current Controversies in Neurosurgery, Saunders, Philadelphia, 1976, pp 67-72. 
50. Beliveau P. A comparison between epidural anaesthesia with and without corticosteroids in the treatment of sciatica. Rheum Phys Med 1971; 11:40-43.

51. Breivik H, Hesla PE, Molnar I et al. Treatment of chronic low back pain and sciatica. Comparison of caudal epidural injections of bupivacaine and methylprednisolone with bupivacaine followed by saline. In Bonica JJ, Albe-Fessard D (eds). Advances in Pain Research and Therapy. Raven Press, New York, 1976, Vol. 1, pp 927-932.

52. Sharma RK. Indications, technique and results of caudal epidural injection for lumbar disc retropulsion. Postgrad Med J 1977; 53:1-6.

53. Yates DW. A comparison of the types of epidural injection commonly used in the treatment of low back pain and sciatica. Rheum Rehab 1978; 17:181-186.

54. Gordon J. Caudal extradural injection for the treatment of low back pain. Anaesthesia 1980; 35:515516.

55. Matthews JA, Mills SB, Jenkins VM et al. Back pain and sciatica: Controlled trials of manipulation, traction, sclerosant and epidural injections. Brit $J$ Rheumatol 1987; 26:416-423.

56. Lindholm R, Salenius P. Caudal epidural administration of anaesthetics and corticosteroids in the treatment of low back pain. Acta Orthop Scand 1978; 49:366-370.

57. Waldman SD. The caudal epidural administration of steroids in combination with local anesthetics in the palliation of pain secondary to radiographically documented lumbar herniated disc: A prospective outcome study with 6-months follow-up. Pain Clinic 1998; 11:43-49.

58. Swerdlow M, Sayle-Creer W. A study of extradural medication in the relief of the lumbosciatic syndrome. Anaesthesia 1970; 25:341-345.

59. Arnhoff FN, Triplett HB, Pokorney B. Follow-up status of patients treated with nerve blocks for low back pain. Anesthesiology 1977; 46:170-178.

60. Bush K, Hillier S. A controlled study of caudal epidural injections of triamcinolone plus procaine for the management of intractable sciatica. Spine 1991; 16:572-575

61. Revel M, Auleley GR, Alaoui S et al. Forceful epidural injections for the treatment of lumbosciatic pain with postoperative lumbar spinal fibrosis. Rev Rhum Engl Ed 1996; 63:270-277.

62. Meadeb J, Rozenberg S, Duquesnoy B et al. Forceful sacrococcygeal injections in the treatment of postdiscectomy sciatica. A controlled study versus glucocorticoid injections. Joint Bone Spine 2001; 68:43-49.

63. Ciocon JO, Galindo-Clocon D, Amarnath L et al. Caudal epidural blocks for elderly patients with lumbar canal stenosis. J Am Geriatr Soc 1994; 42:593596.
64. Manchikanti L, Pampati VS, Rivera JJ et al. Caudal epidural injections with Sarapin or steroids in chronic low back pain. Pain Physician 2001; 4:322-335.

65. Manchikanti L, Singh V, Rivera JJ et al. Effectiveness of caudal epidural injections in discogram positive and negative chronic low back pain. Pain Physician 2002; 5:18-29.

66. Kuslich SD, Ulstrom CL, Michael CJ. The tissue origin of low back pain and sciatica: A report of pain response to tissue stimulation during operation on the lumbar spine using local anesthesia. Orthop Clin North Am 1991; 22:181-187.

67. Bogduk N. Musculoskeletal pain: Toward precision diagnosis. Progress in pain research and management. In Jensen TS, Turner JA, Wiesenfeld-Hallin Z (eds). Proceedings of the 8th World Congress on Pain. IASP Press, Seattle, 1997, pp 507-525.

68. Fortin JD. Precision diagnostic disc injections. Pain Physician 2000; 3:271-288.

69. Sehgal N, Fortin JD. Internal disc disruption and low back pain. Pain Physician 2000; 3:143-157.

70. Carette S, Lecaire R, Marcoux S et al. Epidural corticosteroid injections for sciatica due to herniated nucleus pulposus. N Engl J Med 1997; 336:1634-1640.

71. Frymoyer JW. Lumbar disk disease: Epidemiology. Instr Course Lect 1992; 41:217-223.

72. Saal JA, Saal JS, Herzog RJ. The natural history of lumbar intervertebral disc extrusions treated nonoperatively. Spine 1990; 15:683-686.

73. Bush K, Cowan N, Katz DE et al. The natural history of sciatica associated with disc pathology: A prospective study with clinical and independent radiologic follow-up. Spine 1992; 17:1205-1210.

74. Waddell G. The physical basis of back pain. In The Back Pain Revolution. Churchill Livingstone, New York, 1998, pp 135-154.

75. Maigne JY, Rime B, Delinge B. Computed tomographic follow-up study of forty-eight cases of nonoperatively treated lumbar intervertebral disc herniation. Spine 1992; 17:1071-1074.

76. Delauche-Cavallier MC, Budet C, Laredo JD et al. Lumbar disc herniation: Computed tomography scan changes after conservative treatment of nerve root compression. Spine 1992; 17:927-933.

77. Hitselberger WE, Witten RM. Abnormal myelograms in asymptomatic patients. J Neurosurgery 1968; 28:204-206.

78. Boden SD, Davis DO, Dina TS et al. Abnormal magnetic-resonance scans of the lumbar spine in asymptomatic subjects. J Bone Joint Surg 1990; 72A:403408.

79. Jensen MC, Bran-Zawadzki MN, Obucjowski N et al. Magnetic resonance imaging of the lumbar spine in people without back pain. NEngl J Med 1994; 331:6973.

80. Wiesel SW. A study of computer-assisted tomogra- 
phy. 1. The incidence of positive CAT scans in an asymptomatic group of patients. Spine 1986; 9:549551.

81. Devor M. Pain arising from the nerve root and the dorsal root ganglia and chronically injured axons: A physiological basis for the radicular pain of nerve root compression. Pain 1977; 3:25-41.

82. Olmarker K, Rydevik B, Holm S. Edema formation in spinal nerve roots induced by experimental, graded compression: An experimental study on the pig cauda equina with special reference to differences in effects between rapid and slow onset of compression. Spine 1989; 14:569-573.

83. Yoshizawa H, Nakai S, Koboyashi $\mathrm{S}$ et al. Intraradicular edema formation as a basic factor in lumbar radiculopathy. In Weinstein JN, Gordon SL (eds). Low Back Pain: A Scientific and Clinical Overview. American Academy of Orthopaedic Surgeons, Rosemont, IL, 1996, pp 235-246.

84. Olmarker K, Rydevik B, Holm B et al. Effects of experimental graded compression on blood flow in spinal nerve roots: A vital microscopic study on the porcine cauda equina. J Orthop Res 1989; 7:817-823.

85. Olmarker K. Mechanical and biochemical injury of spinal nerve roots: An experimental perspective. In Weinstein JN, Gordon SL (Eds). Low Back Pain: A Scientific and Clinical Overview. American Academy of Orthopaedic Surgeons, Rosemont, IL, 1996, pp 215233.

86. O’Neill C, Derby R, Kenderes L. Precision injection techniques for diagnosis and treatment of lumbar disc disease. Sem Spine Surg 1999; 11:104-118.

87. Manchikanti L. Transforaminal lumbar epidural steroid injections. Pain Physician 2000; 3:374-398.

88. Slipman CW, Isaac Z. The role of diagnostic selective nerve root blocks in the management of spinal pain. Pain Physician 2001; 4:214-226.

89. Fredman B, Nun MB, Zohar E et al. Epidural steroids for treating "failed back surgery syndrome:" Is fluoroscopy really necessary? Anesth Analg 1999; 88:367372.

90. Mehta M, Salmon N. Extradural block. Confirmation of the injection site by X-ray monitoring. Anaesthesia 1985; 40:1009-1012.

91. Burn JM, Guyer PB, Langdon L. The spread of solutions injected into the epidural space: A study using epidurograms in patients with lumbosciatic syndrome. Br J Anaesth 1973; 45:338-345.

92. Nishimura N, Khahara T, Kusakabe T. The spread of lidocaine and 1-131 solution in the epidural space. Anesthesiology 1959; 20:785-788.

93. Bromage RP, Benumof JL. Paraplegia following intracord injection during attempted epidural anesthesia under general anesthesia. Reg Anesth Pain Med 1998; 23:104-107.

94. Krane EJ, Dalens BJ, Murat I et al. The safety of epidurals during general anesthesia. Reg Anesth Pain Med 1998; 23:433-438.

95. Manchikanti L, Bakhit CE, Pampati V. Role of epidurography in caudal neuroplasty. Pain Digest 1998; 8:277-281.

96. Renfrew DL, Moore TE, Kathol MH, et al. Correct placement of epidural steroid injections: Fluoroscopic guidance and contrast administration. AJNR 1991; 12:1003-1007.

97. El-Khoury GY, Ehara S, Weinstein JN, et al. Epidural steroid injection: A procedure ideally performed with fluoroscopic control. Radiology 1988; 168:554-557.

98. Stewart HD, Quinnel RC, Dann N. Epidurography in the management of sciatica. Brit J Rheumatol 1987; 26:424-429.

99. Lewis MP, Thomas P, Wilson LF et al. The 'whoosh' test. A clinical test to confirm correct needle placement in caudal epidural injections. Anaesthesia 1992; 47:57-58.

100. Hatten, HP Jr. Lumbar epidurography with metrizamide. Radiology 1980; 137:129-136.

101. Maigne JY, Gourjon A, Maigne R. Taux de Reussite des Trois Techniques d'injection epidurale: Etude de l'Etalement d'un Contraste Radio-opaque. Revue du Rhumatisme 1990; 57:575-578.

102. Eastwood D, Williams C, Buchan I. Caudal epidurals: The whoosh test. Anaesthesia 1998; 53:305-307.

103. Stitz MY, Sommer HM. Accuracy of blind versus fluoroscopically guided caudal epidural injection. Spine 1999; 24:1371-1376.

104. Price CM, Rogers PD, Prosser AS et al. Comparison of the caudal and lumbar approaches to the epidural space. Ann Rheum Dis 2000; 59:879-882.

105. Bresgen C. Uber Ischiassimulation die diagnostische. Bedeutung der epidural Novocaininjection. München Med Wchnschr 1951; 93:934.

106. Sullivan WJ, Willick Se, Chira-Adisai W et al. Incidence of intravascular uptake in lumbar spinal injection procedures. Spine 2000; 25:481-486.

107. Botwin KP, Gruber RD, Bouchlas CG et al. Complications of fluoroscopically guided caudal epidural injections. Am J Phys Med Rehabil 2001; 80:416-424.

108. Andrade A, Eckman E. The distribution of radiologic contrast media by lumbar translaminar and selective neural canals in normal human volunteers. In Proceedings of the Annual Meeting of the International Spinal Injection Society. Keystone, CO, January 1992.

109. Saal JS, Saal JA. Comprehensive cervical and lumbar intra-spinal injection course. Stanford University School of Medicine, Stanford, CA, July 11-12, 1998.

110. Gertzbein SD. Degenerative disk disease of the lumbar spine. Immunological implications. Clin orthop 1977; 129:68-71.

111. Gertzbein SD, Tile M, Gross A et al. Autoimmunity in degenerative disk disease of the lumbar spine. Orthop Clin North Am 1975; 6:67-73. 
112. Irsigler FJ. Kidroskopishe Befunde in den Ruckenlarkswurzeln beim lumbalen und lumbosakralen (dorsolateral) Diskusprolaps. Acta Neurochi (Wein) 1951; 1:478-516.

113. Lindblom K, Rexed B. Spinal nerve injury in dorsolateral protrusions of lumbar disks. J Neurosurg 1949; 5:413-432.

114. Marshall LL, Trethewie EW, Curtain CC. Chemical irritation of nerve-root in disc prolapse. Lancet 1973; 2:320.

115. Marshall LL, Trethewie EW, Curtain CC. Chemical radiculitis. A clinical, physiological, and immunological study. Clin Orthop 1977; 129:61-67.

116. McCarron RF, Wimpee MW, Hudkins PG et al. The inflammatory effect of nucleus pulposus: A possible element in the pathogenesis of low back pain. Spine 1987; 12:758-764.

117. Murphy RW. Nerve roots and spinal nerves in degenerative disk disease. Clin Orthop 1977; 129:46-60.

118. Saal JS, Franson RC, Dobrow R et al. High levels of inflammatory phospholipase $\mathrm{A}_{2}$ activity in lumbar disc herniations. Spine 1990; 15:674-678.

119. Park WW, Watanabe RYO. The intrinsic vasculature of the lumbosacral spinal nerves. Spine 1985; 10:508515.

120. Kayama S, Konno S, Olmarker K et al. Incision of the annulus fibrosus induces nerve root morphologic, vascular, and functional changes. Spine 1996; 21:25392543.

121. Rydevik B, Brown MD, Ludborg G. Pathoanatomy and pathophysiology of nerve root compression. Spine 1984; 9:7-15.

122. Chaoyang C, Cavanaugh JM, Ozaktaky C et al. Effects of phospholipase $A_{2}$ on lumbar nerve root structure and function. Spine 1997; 22:1057-1064.

123. Ryan MD, Taylor TKF. Management of lumbar nerveroot pain. Med J Aust 1981; 2:532-534.

124. Fox AJ, Melzack R. Transcutaneous electrical stimulation to acupuncture. Comparison of treatment of low back pain. Pain 1976; 2:141-148.

125. Fowler RJ, Blackwell GJ. Anti-inflammatory steroid induced biosynthesis of a phospholipase $\mathrm{A}_{2}$ inhibitor which prevents prostaglandin generation. Nature 1979; 278:456-459.

126. Devor M, Govrin-Lippmann R, Raber P. Corticosteroids suppress ectopic neural discharges originating in experimental neuromas. Pain 1985; 22:127-137.

127. Hua SY, Chen YZ. Membrane receptor-mediated electrophysiological effects of glucocorticoid on mammalian neurons. Endocrinology 1989; 124; 687-691.

128. Johansson A, Hao J, Sjolund B. Local corticosteroid application blocks transmission in normal nociceptor C-fibers. Acta Anaesthesiol Scand 1990; 34:335-338.

129. Faber LE, Wakim NG, Duhring JL. Evolving concepts in the mechanism of steroid action: Current developments. Am J Obstet Gynecol 1987; 156:1449-
1458.

130. Olmarker K, Byrod G, Cornefijord M et al. Effects of methylprednisolone on nucleus pulposus-induced nerve root injury. Spine 1994; 19:1803-1808.

131. Nicol GD, Klingberg DK, Vasko MR. Prostaglandin E2 enhances calcium conductance and stimulates release of substance $\mathrm{P}$ in avian sensory neurons. $J$ Neurosci 1992; 12:1917-1927.

132. Coderre $\mathrm{T}$. Contribution of protein kinase $\mathrm{C}$ to central sensitization and persistent pain following tissue injury. Neurosci Lett 1992; 140:181-184.

133. Hayashi N, Weinstein JN, Meller ST et al. The effect of epidural injection of betamethasone or bupivacaine in a rat model of lumbar radiculopathy. Spine 1998; 23:877-885.

134. Lee HM, Weinstein JN, Meller ST et al. The role of steroids and their effects on phospholipase $\mathrm{A}_{2}$. An animal model of radiculopathy. Spine 1998; 23:11911196.

135. Minamide A, Tamaki T, Hashizume H et al. Effects of steroids and lipopolysaccharide on spontaneous resorption of herniated intervertebral discs. An experience study in the rabbit. Spine 1998; 23:870-876.

136. Johansson A, Bennett GJ. Effect of local methylprednisolone on pain in a nerve injury model. A pilot study. Reg Anesth 1997; 22:59-65.

137. Kingery WS, Castellote JM, Maze M. Methylprednisolone prevents the development of autotomy and neuropathic edema in rats, but has no effect on nociceptive thresholds. Pain 1999; 80:555-566.

138. Kantrowitz F, Robinson DR, McGuire MB et al. Corticosteroids inhibit prostaglandin production by rheumatoid synovia. Nature 1975; 258:737-739.

139. Byrod G, Otani K, Brisby H et al. Methylprednisolone reduces the early vascular permeability increase in spinal nerve roots induced by epidural nucleus pulposus application. J Orthop Res 2000; 18:983-987.

140. Manchikanti L. The value and safety of steroids in neural blockade, Part I. AJPM 2000; 10:69-78.

141. Manchikanti L. The value and safety of steroids in neural blockade, Part II. AJPM 2000; 10:121-133.

142. Olmarker K, Blomquist J, Stromberg J et al. Inflammatogenic properties of nucleus pulposus. Spine 1995; 20:665-669.

143. Kang JD, Georgescu HI, McIntyre-Larkin L et al. Herniated lumbar intervertebral discs spontaneously produce matrix metalloproteinases, nitric oxide, interleukin-6, and prostaglandin E2. Spine 1996; 21: 271-277.

144. Olmarker K, Rydevik B, Nordborg C. Autologous nucleus pulposus induces neurophysiologic and histologic changes in porcine cauda equina nerve roots. Spine 1993; 181:1425-1432.

145. Gronblad M, Virri J, Tolonen J et al. A controlled immunohistochemical study of inflammatory cells in disc herniation tissue. Spine 1994; 19:2744-2751. 
146. Jaffray D, O’Brien JP. Isolated intervertebral disc resorption: A source of mechanical and inflammatory back pain? Spine 1986; 11:397-401.

147. Kawakami M, Tamaki T, Hashizume $\mathrm{H}$ et al. The role of phospholipase A2 and nitric oxide in pain-related behavior produced by an allograft of intervertebral disc material to the sciatic nerve of the rat. Spine 1997; 22:1074-1079.

148. Saal JS. The role of inflammation in lumbar pain. Spine 1995; 20:1821-1827.

149. Thelander U. Fagerlung M., Friberg S et al. Straight leg raising test vs radiologic size, shape, and position of lumbar disc herniations. Spine 1992; 17:395-389.

150. Haldeman S. Failure of the pathological model to predict back pain. Spine 1990; 15:718-732.

151. Spangfort EV. The lumbar disc herniation. A computer aided analysis of 2504 operations. Acta Orthop Scand (Suppl) 1972; 142:1-95.

152. Weber H. Lumbar disc herniations: A controlled prospective study with ten years of observation. Spine 1983; 8:131-140.

153. Detailed Diagnosis and Procedures, National Hospital Discharge Survey 1986, 1987. National Center for Health Statistics, Vital and Health Statistics. U.S. Department of Health and Human Services, Rockville, MD, 1988-1989.

154. Dilke TFW, Burry JC, Grahame R. Extradural corticoid injection in management of lumbar nerve root compression. Brit Med J 1973; 2:635-637.

155. Green LN. Dexamethasone for lumbar radiculopathy. J Neurol Neurosurg Psychiatry 1975; 38:12.

156. Weinstein J, Claverie J. The pain of discography. Spine 1988; 13:1444-1448.

157. Saal JA, Saal JS. Nonoperative treatment of herniated lumbar intervertebral disc with radiculopathy: An outcome study. Spine 1989; 14:431-437.

158. Korovessis PG. The role of steroids and their effects on phospholipase A, Spine 2000; 25:2004.

159. Koes BW, Bouter LM, Van Der Heijden GJMGV. Methodological quality of randomized clinical trials on treatment efficacy in low back pain. Spine 1995; 20:228-235.

160. Van Tulder MW, Koes BW, Bouter LM. Conservative treatment of acute chronic nonspecific low back pain. A systematic review of randomized controlled trials of the most common interventions. Spine 1997; 22:21282156.

161. Van Tulder MW, Goossens M, Waddell G et al. Conservative treatment of chronic low back pain. In Nachemson AL, Jonsson E (eds). Neck and Back Pain. Lippincott Williams and Wilkins, Philadelphia, 2000, pp 271-304.

162. Bigos SJ, Boyer OR, Braen GR et al. Acute Low Back Problems in Adults. Clinical Practice Guideline Number 4. AHCPR Publication No. 95-0642. Agency for Health Care Policy and Research, Public Health Ser- vice, US Department of Health and Human Services, Rockville, MD, December 1994.

163. Manchikanti L, Kloth D, Singh V. The role of guidelines in interventional pain medicine: Let us separate apples and oranges. Pain Physician 2001; 4:13-23.

164. Manchikanti L, Bakhit CE, Pakanati RR et al. Fluoroscopy is medically necessary for the performance of epidural steroids. Anesth Analg 1999; 89:1326-1327. Benson K, Hartz AJ. A comparison of observational studies and randomized, controlled trials. New Engl J Med 2000; 342:1878-1886.

166. Concato J, Shah N, Horwitz RI. Randomized, controlled trials, observational studies, and the hierarchy of research designs. N Engl J Med 2000; 342:18871892.

167. Abram SE, O'Connor TC. Complications associated with epidural steroid injections. Reg Anesth 1996; 212 : 149-162.

168. Nelson DA. Intraspinal therapy using methylprednisolone acetate. Spine 1993; 18:278-286.

169. Kushner FH, Olson JC. Retinal hemorrhage as a consequence of epidural steroid injection. Arch Ophthalmol 1995; 113:309-313.

170. Ling C, Atkinson PL, Munton CG. Bilateral retinal hemorrhages following epidural injection. $\mathrm{Br} J$ Ophthalmol 1993; 77:316-317.

171. Purdy EP, Ajimal GS. Vision loss after lumbar epidural steroid injection. Anesth Analg 1998; 86:119-122.

172. Victory RA, Hassett P, Morrison G. Transient blindness following epidural analgesia. Anesthesia 1991; 46:940-941.

173. Clark CJ, Whitwell J. Intraocular hemorrhage after epidural injection. Brit Med J 1961; 2:1612-1613.

174. Usubiaga JE, Wikinski JA, Usubiaga LE. Epidural pressure and its relation to spread of anesthetic solution in epidural space. Anesth Analg 1967; 46:440446.

175. Morris DA, Henkind P. Relationship of intracranial, optic-nerve sheath, and retinal hemorrhage. Am J Ophthalmol 1967; 64:853-859.

176. Sampath P, Rigamonti D. Spinal epidural abscess: A review of epidemiology, diagnosis, and treatment. $J$ Spinal Disord 1999; 12:89-93.

177. Wang LP, Haverberg J, Schmidt JF. Incidence of spinal epidural abscess after epidural analgesia. Anesthesiology 1999; 91:1928-1936.

178. Rathmell JP, Garahan MB, Alsofrom GF. Epidural abscess following epidural analgesia. Reg. Anesth Pain Med 2000; 25:79-82.

179. Baker AS, Ojemann RG, Swartz MN et al. Spinal epidural abscess. N Engl J Med 1975; 293:463-468.

180. Knight JW, Cordingley JJ, Palazzo MGA. Epidural abscess following epidural steroid and local anaesthetic injection. Anaesthesia 1997; 52:576-585.

181. Tryba M. Epidural regional anesthesia and low molecular heparin: Pro (German). Anasth Intensivmed 
Notfallmed Schmerzher 1993; 28:179-181.

182. Vandermeulen EP, Van Aken H, Vermylen J. Anticoagulants and spine-epidural anesthesia. Anesth Analg 1994; 79:1165-1177

183. Sandhu H, Morley-Fost P, Spadafora S. Epidural hematoma following epidural analgesia in a patient receiving unfractionated heparin for thromboprophylaxis. Reg Anesth Pain Med 2000; 25:72-75.

184. Rigler ML, Drasner K, Krejcie TC et al. Cauda equina syndrome after continuous spinal anesthesia. Anesth Analg 1991; 72:275-281.

185. Adams HJ, Mastri AR, Eicholzer et al. Morphologic effects of intrathecal etidocaine and tetracaine on the rabbit spinal cord. Anesth Analg 1974; 53:904-908.

186. Kalichman MW, Powell HC, Myers RR. Quantitative histologic analysis of local anesthetic-induced injury to rat sciatic nerve. J Pharmacol Exp Ther 1989; 250:406-413.

187. Ready LB, Plumer MH, Haschke RH et al. Neurotoxicity of intrathecal local anesthetics in rabbits. Anesthesiology 1985; 63:364-370.

188. Nicholson MJ, Eversole UH. Neurologic complications of spinal anesthesia. JAMA 1946; 132:679-685.

189. Schneider M, Ettlin T, Kaufmann M et al. Transient neurologic toxicity after hyperbaric subarachnoid anesthesia with 5\% lidocaine. Anesth Analg 1993; 76:1154-1157.

190. Horlocker TT, Wedel DJ. Neurologic complications of spinal and epidural anesthesia. Reg Anesth Pain Med 2000; 25:83-98.

191. Wong CA, Benzon H, Kim C. Bilateral radicular pain after epidural lidocaine. Reg Anesth 1996; 21: 600601.

192. Shantha TR, Evans JA. The relationship of epidural anesthesia to neural membranes and arachnoid villi. Anesthesiology 1972; 37:543-557.

193. Fitzgibbon DR. Liability arising from anesthesiologybased pain management in the nonoperative setting. ASA Newsletter 2001; 65:12-15.

194. Cheney FW. High-severity injuries associated with regional anesthesia in the 1990s. ASA Newsletter 2001; 65:6-8.

195. Kane RE. Neurologic deficits following epidural or spinal anesthesia. Anesth Analg 1981; 60:150-161.

196. Delaney TJ, Rowlingson JC, Carron H et al. Epidural steroid effects on nerves and meninges. Anesth Analg 1980; 58:610-614.

197. Cicala RS, Turner R, Moran E et al. Methylprednisolone acetate does not cause inflammatory changes in the epidural space. Anesthesiology 1990; 72:556-558.

198. MacKinnon SE, Hudson AR, Gentilli R et al. Peripheral nerve injection injury with steroid agents. Plast Reconstr Surg 1982; 69:482-489.

199. Chino N, Awad EA, Kottke FJ. Pathology of propylene glycol administered by perineural and intramuscular injection in rats. Arch Phys Med Rehab 1974; 55:33-38.
200. Benzon HT, Gissen AJ, Strichartz GR et al. The effect of polyethylene glycol on mammalian nerve impulses. Anesth Analg 1987; 66:553-559.

201. Abram SE, Marsala M, Yaksh TL. Analgesic and neurotoxic effects of intrathecal corticosteroids in rats. Anesthesiology 1994; 81:1198-1205.

202. Latham JM, Fraser RD, Moore RJ et al. The pathologic effects of intrathecal betamethasone. Spine 1997; 22:1558-1562.

203. Slucky AV, Sacks MS, Pallares VS et al. Effects of epidural steroids on lumbar dura material properties. J Spinal Disord 1999; 12:331-340.

204. Manchikanti L, Pampati V, Beyer C et al. The effect of neuraxial steroids on weight and bone mass density: A prospective evaluation. Pain Physician 2000; 3:357-366.

205. Knight CL, Burnell JC. Systemic side-effects of extradural steroids. Anesthesia 1980; 35: 593-594.

206. Edmonds JC, Vance ML, Hughes JM. Morbidity from paraspinal depo corticosteroid injections for analgesia. Cushing's syndrome and adrenal suppression. Anesth Analg 1991; 72:820-822.

207. Jacobs A, Pullan PT, Potter JM et al. Adrenal suppression following extradural steroids. Anesthesia 1983; 38:953-956.

208. Mikhail GR, Sweet LC, Mellinger RC. Parenteral longacting corticosteroid effect on hypothalamic pituitary adrenal function. Ann Allergy 1973; 31: 337-343.

209. Mikhail GR, Livingood CS, Mellinger RC et al. Effect of long-acting parenteral corticosteroids on adrenal function. Arch Dermatol 1969; 100: 263-268.

210. Melby JC. Drug spotlight program. Systemic corticosteroid therapy. Pharmacology and endocrinologic considerations. Ann Intern Med 1974; 81:505-512.

211. Schimmer BP, Parker KL. Adrenocorticotropic hormone; adrenocortical steroids and their synthetic analogs; inhibitors of the synthesis and actions of adrenocortical hormones. In Hardman JG, Molinoff PB, Ruddon RW (eds). Goodman's \& Gilman's, The Pharmacological Basis of Therapeutics. ed 9. McGrawHill, New York, 1996, pp 1459-1485.

212. McEvoy GK, Littvak K, Welsh OH et al. AHFS 2000 Drug Information. American Society of Health-System Pharmacists, Bethesda, 2000, pp 2738-2765.

213. Roonen S, Van Distel G, Westhovens R et al. Steroid myopathy induced by epidural triamcinolone injection. Brit J Rheumatol 1995; 34: 385.

214. Roy-Camille R, Mazel CH, Husson JL et al. Symptomatic spinal epidural lipomatosis induced by a longterm steroid treatment. Spine 1991; 16:1365-1371.

215. Cousins MJ. An additional dimension to the efficacy of epidural steroids. Anesthesiology 2000; 93:565.

216. Johns KJ, Chandra SR. Visual loss following intranasal corticosteroid injection. JAMA 1989; 261:2413.

217. Abram S. An additional dimension to the efficacy of epidural steroids. Anesthesiology 2000; 93:566. 